\title{
The Application Of Model 7ps Marketing Mix At STKIP Weetebula
}

\author{
Wilhelmus Yape Kii ${ }^{1}$ \\ ${ }^{1}$ Sekolah Tinggi Keguruan dan Ilmu Pendidikan Weetebula.
}

*Corresponding Author: Wilhelmus Yape Kii, STKIP Weetebulae;

Email: wyape@yahoo.com

\begin{abstract}
This paper describes the marketing planning of STKIP Weetebula to increase the number of STKIP Weetebula students according to the Medium and Long Term Development Strategy of STKIP Weetebula. The first part of this paper explains about marketing, marketing model management, stakeholder analysis and continues with explanations about STKIP Weetebula.

In the second part, the key stakeholders are defined using the stakeholder matrix. Once key stakeholders are determined, the next step is to make marketing planning for key stakeholders. There are several marketing planning models that can be used by education institutions to develop a marketing planning. STKIP Weetebula choose the $7 \mathrm{P}$ marketing mix because it is a marketing planning model that is quite widely used in higher education organizations and considered suitable for educational institutions such as STKIP Weetebula.
\end{abstract}

Keywords: marketing planning for higher institution, stakeholder analysis

\section{Introduction}

\section{Introduction to Marketing}

Marketing is a social and managerial process in which individuals and groups get their needs and wants by creating, offering, and exchanging something of value to each other. "Marketing is the analysis, planning, implementation, and control of the appropriately prepared voluntary exchanges of values with target markets to achieve institutional objectives. Marketing involves designing the institution's affairs to meet the target markets needs and desires, and effective pricing, communication, and distribution to inform, motivate, and service these markets " (Kotler and Fox, 1995: 6).

Gibbs and Knapp, (2002: 39-51) classifies several key elements of marketing:(1) Competition strategy elements, including: (a) Market segmentation, which is the act of identifying and forming groups of buyers or consumers separately. Each of these consumers has his/her own characteristics, product requirements, and mixed marketing mix. (b) Targetting, which is the act of selecting one or more market segments to be entered. (c) Positioning, i.e. the determination of market position. The goal is to build and communicate the competitive advantage of existing products in the market into the minds of consumers.(2) Elements of marketing tactics, including:(a) Differentiation, related to how to build marketing strategies across various aspects of the company. Activity building marketing strategy is what distinguishes differentiation of a company with other companies.(b) Marketing mix, related to activities regarding product, price, promotion, and place or better known as 4P.(3) The element of marketing value, relating to: name, termin, symbol or design, or combination, aimed at identifying the goods of a seller and differentiating them from competitors.

Understanding Education Services

To understand the meaning of educational services, Kotler (2003: 428), a marketing expert, proposes the meaning of aservice "is any act or performance that a party is not intangible and does not result in the ownership of anything. Its production may or may not be tied to a physical product". The meaning of services is any action offered by one party to another party that is intangible and does not lead to the transfer of ownership. In relationto education, it can be said that education as a service product is something intangible but can meet the needs of consumers who process by using or not using the help of physical products where the process that occurs is the interaction between service providers with service users that does not result in the transfer of right or ownership. Referring to this understanding, there are four main characteristics in each service, namely:

a. Intangibileity that consumers can not see, smell, touch, hear, and feel the results before they buy it. 
To reduce uncertainty, consumers seek information about the services;

b. Inseparability, where services can not be separated from the source of the service company;

c. Variability, where services often vary depending on who, when, and where to present them;

d. Easy perishability, services can not be sold in the future.

Based on these characteristics, the education services have the following characteristics:

- More intangible than tangible;

- Simultananeous production and consumption;

- Less standardized and uniform.

\section{The Stakeholder Analysis}

This section explainsthe meaning of stakeholders and stakeholder analysis. Stake holders are any individual or organizations that can have a positive or negative impact or those affected by what the organization does.Stakeholder analysis is a process of identifying both individuals and groups that will influence or be influenced by an action to be performed and categorized according to the impact of the action taken. The purpose of stakeholder analysis is to build cooperation between stakeholders and the institutional planning team in the program of making and implementing the marketing plan to ensure the institution's objectives are achieved. Stakeholder analysis can help to clarify the consequences that occur in case of program changes. The information obtained will be used to conduct an evaluation before the action is taken to allow preventive efforts.

(https://www.mindtools.com/pages/article/newPPM_07. htm).

Stages of the stake holder analysis are:

1. Identify all stakeholders both internal and external;

2. Identify stakeholder needs and interests (interest);

3. Identify the interests of its stakeholders (using stakeholder mapping);

4. Identify areas of conflict between stakeholders and stakeholders, organizations with stakeholders;

5. Prioritize, synchronize, balance stakeholders;

6. Align stakeholder needs with the organization.

\section{Marketing management models}

\section{Marketing models}

There are many marketing models have been developed over the years, some of these models are more applicable in the real world, particularly on education sector than others, for examplethe McKinsey 7S model, the 7Ps of the Marketing Mix, AIDA (Attention/Awarness, Interest, Desire, and Action), The Ansoff's model, The Boston Consulting Group (BCG) Matrix, Diffusion of Innovation, Porter's Five Forces, Price-Quality-Strategy Model, Push and Pull Marketing, Product Lifecycle, Segmentation, Targeting and Positioning (STP), and
SWOT (TOWS) Matrix.

It is important that we pickup and explain the most useful, adaptable, and pratical model for higher institution. Here a brief overview of several marketing planning models that have been developed in the last few years is provided.

\begin{tabular}{|c|c|}
\hline $\begin{array}{l}\text { Marketin } \\
\text { g } \\
\text { Planning } \\
\text { Model }\end{array}$ & Overview \\
\hline $\begin{array}{l}\text { The } \\
\text { Ansoff's } \\
\text { model. }\end{array}$ & $\begin{array}{l}\text { The Ansoff's model is a matrix that could } \\
\text { identify alternative growth strategies by } \\
\text { looking at present and potential products in } \\
\text { the current and future markets. There are } \\
\text { four growths strategies that can be used such } \\
\text { as market penetration, market develoments, } \\
\text { product development, and diversification. } \\
\text { According to Gibbs and Knapp, }(2002 \text { : } \\
\text { 15)this model is one of the best formats for } \\
\text { mapping strengths and weaknesses for } \\
\text { institutions. }\end{array}$ \\
\hline $\begin{array}{l}\text { The } \\
\text { McKinse } \\
\text { y 7S } \\
\text { model }\end{array}$ & $\begin{array}{l}\text { The McKinsey } 7 \mathrm{~S} \text { is a marketing planning } \\
\text { model that can be used to review the } \\
\text { effectiveness of an organisation in its } \\
\text { marketing operations, determine how to best } \\
\text { realign an organisation to support a new } \\
\text { strategic direction and to asses the changes } \\
\text { needed by an organisation. } \\
\text { The } 7 \mathrm{~S} \text { framework was founded by } \\
\text { McKinsey consultants in the } 1970 \text { s then } \\
\text { further developed in } 1980 \text { by } \\
\text { Waterman. The } 7 \mathrm{~S} \text { of this model can be } \\
\text { seen in the figure below. }\end{array}$ \\
\hline
\end{tabular}




\begin{tabular}{|l|l|}
\hline & $\begin{array}{l}\text { product or service. } \\
\text { 2. INTEREST in paying attention to the } \\
\text { product's benefits. } \\
\text { 3. DESIRE for the product. } \\
\text { 4. ACTION in purchasing the product. }\end{array}$ \\
\hline SWOT & $\begin{array}{l}\text { A SWOT (TOWS) allows an organization, } \\
\text { for example education institution, to develop } \\
\text { a strategy or plan of action based on the } \\
\text { situation in the marketplace. It considers the } \\
\text { organisation's existing capabilities for } \\
\text { marketing against competitors and looks at } \\
\text { opportunities in the future. } \\
\text { A SWOT explains the internal strategic } \\
\text { strengths and weaknesses of a marketing } \\
\text { strategy and the external strategic } \\
\text { opportunities and threats that are available } \\
\text { to all competitors in a market. The TOWS } \\
\text { matrix reviews not only the situation through } \\
\text { internal strengths and weaknesses and } \\
\text { external opportunities and threats around the } \\
\text { edge, but also shows } 4 \text { boxes for creating } \\
\text { strategies to succeed in the marketplace. } \\
\text { This model helps define future direction } \\
\text { rather than just focusing on the present } \\
\text { (Weihrich, 1982). The } 4 \text { boxes for creating } \\
\text { strategies can be seen in the figure 1.2. } \\
\text { below. }\end{array}$ \\
\hline
\end{tabular}

\begin{tabular}{|c|l|l|}
\hline The Organisation & \multicolumn{1}{|c|}{ Strengths-S } & \multicolumn{1}{|c|}{ Weakness-W } \\
\hline Opportunities-O & $\begin{array}{l}\text { SO strategies } \\
\text { Leverage } \\
\text { strengths } \\
\text { maximize } \\
\text { opportunities } \\
\text { (attacking } \\
\text { strategies) }\end{array}$ & $\begin{array}{l}\text { WO strategies } \\
\text { Counter } \\
\text { weaknesses } \\
\text { through } \\
\text { exploiting } \\
\text { opportunities } \\
\text { (build strength } \\
\text { for attacking } \\
\text { strategies) }\end{array}$ \\
\hline Threats-T & $\begin{array}{l}\text { ST strategies } \\
\text { Leverage } \\
\text { strengths } \\
\text { minimize } \\
\text { threats } \\
\text { (defensive } \\
\text { strategies) }\end{array}$ & $\begin{array}{l}\text { WT strategies } \\
\text { Counter } \\
\text { weaknesses and } \\
\text { threats (build } \\
\text { strength for } \\
\text { defensive } \\
\text { strategy }\end{array}$ \\
\hline
\end{tabular}

Figure 2. The 4 boxes for creating strategies. (Weihrich, 1982).

\section{The 7Ps (Marketing mix)}

The 7 Ps of marketing mix model are product, price, place, promotion, people, physical evidences, and process. According to Kotler and Armstrong (1999: 113114), the marketing mix is a tactical and controllable tool of marketing plan to generate the desired response of the organisation in the target market."The marketing mix consists of everything the firm can do to influence the demand for its product".
The traditional marketing-model 4P (product, price, place, promotion) has been extended to $7 \mathrm{P}$ (people, physical evidence, process) to meet the need of companies/organizations in the service sector (Kotler and Fox, 1995: 8). The 7Ps model may enable institutions in the service sector to address the market situation and to follow objectives. The influence or impact of eachelement of the 7 Ps to the marketing plan of an institution can be different. A new institution may concentrate on few elements of the $7 \mathrm{P}$ for example the product, price and promotion, while a mature institution will apply all elements of developing its marketing plan. It is important to consider each strategy one at a time, the interdependence and the relationship of each element to the other should be taken into consideration during the application process of the framework.

Elements of the marketing mix are as follow:

a. Product (product)

A product is not only in the form of something tangible, such as food, drinks and so on but also something intangible like service.Products can be grouped into three groups based on durability and their embodiment according to Kotler, (2002: 215) are:

1. Goods are not durable, ie tangible goods that are usually consumed in one or several uses.

2. Durable goods, ie tangible goods that can generally be used long enough.

3. Services, a series of activities, benefits, or satisfaction offered for sale.

\section{b. Price (Price)}

Kotler and Amstrong, (1999:110) mentioned thatprice is the only element in the marketing mix that generates revenue and is one of the most flexible elements of the marketing mix, where it can be changed quickly. In addition, there are six procedure steps to settle the price as follows:

1. Choose a pricing goal;

2. Determine the demand;

3. Estimating cost;

4. Analyze competitors' costs, prices, and offers;

5. Choosing a pricing method;

6. Choosing the final price;

\section{c. Place / Location (Place)}

For the company, the location means as a place where the service is provided. A good location is a convenient location without the huge cost and long time to get there. According to Lupiyodi (2001: 62), there are three types of interactions that affect the location, namely:

1. Consumer comes to the service provider.

2. Service providers come to the consumer.

3. Service providers and consumers do not meet directly 


\section{d. Promotion (Promotion)}

Kotler and Armstrong (1999: 110) stated that "Promotion means activities that communicate product superiority and persuade customers the next means".

According to Gibbs and Knapp, (2002: 75) the traditional ways in promotion has four key elements:

1. advertising;

2. face-to-face promotions;

3. public relations; and

4. personal selling.

\section{e. People (People)}

People are human resources that need to be maintained and developed in order to contribute to aorganisation. In a service institution, people/employees are part of the work of theinstitution that can provide services for consumers.Kotler and Amstrong (1999:11) stated that the definition of services "are activities or benefits offered for sale that are essentially intangible and do not result in the ownership of anything. Examples are banking, airline, hotel, and household appliance repair services.

\section{f. Process (Process)}

The process involves the work of the company in providing services to consumers in the provision of dishes.Tjiptono (2000: 146) stated that the process is a "superior service company". This work process begins from the consumer entering until to get out of the company. This work process involves the speed and accuracy of work. If the process is quickly done, then the consumer will be satisfied.

\section{g. Physical Evidence}

Place or physical evidence is one nature of marketing mix that is not fixed and changeable. Good marketing management gives customers satisfaction. The organisation will not sell the products at random, it sells or buys quality products in a timely manner and at a decent price and in a good place.

\section{Model 7Ps Marketing Mix is used to develop a marketing planning for STKIP Weetebula}

\section{STKIP Weetebula}

STKIP Weetebula was founded by the District of Southwest Sumba, Bishop of Weetebula and YAPNUSDA in 2013. STKIP Weetebula has a 100-ha campus that is located in Karuni Village, Loura SubDistrict, Southwest Sumba District. The campus is about $6 \mathrm{~km}$ from downtown Weetebula, $5 \mathrm{~km}$ from Tambolaka Airport, and $12 \mathrm{~km}$ from the Waikelo Harbour.

Vision STKIP Weetebula

STKIP Weetebula's vision is "making STKIP Weetebula a higher education institution that produces professional teachers who can be a model, building willingness and develop creativity of learners". (RIP STKIP Weetebula, 2015)

Students, lecturers and Staff

Currently, STKIP Weetebula already has 1377 students at 4 study programs: Primary School Teacher Education (PGSD), Indonesian Language Education, Mathematics Education, and Physics Education. The PGSD is a favorite study program in STKIP Weetebula because of the high demand of primary school teachers in Sumba Island since 2009. The high demand to enrol at PGSD is because the job opportunity to become elementary school teacher in Sumba Island is bigger compared to other study programs. STKIP Weetebula has 46 permanent lecturers and 37 contract lecturers (80\% with master degree). STKIP has 44 (16 permanent and 28 contract)of supporting staffs. The organizational structure of STKIP Weetebula can be seen in the Figure 3 below. 


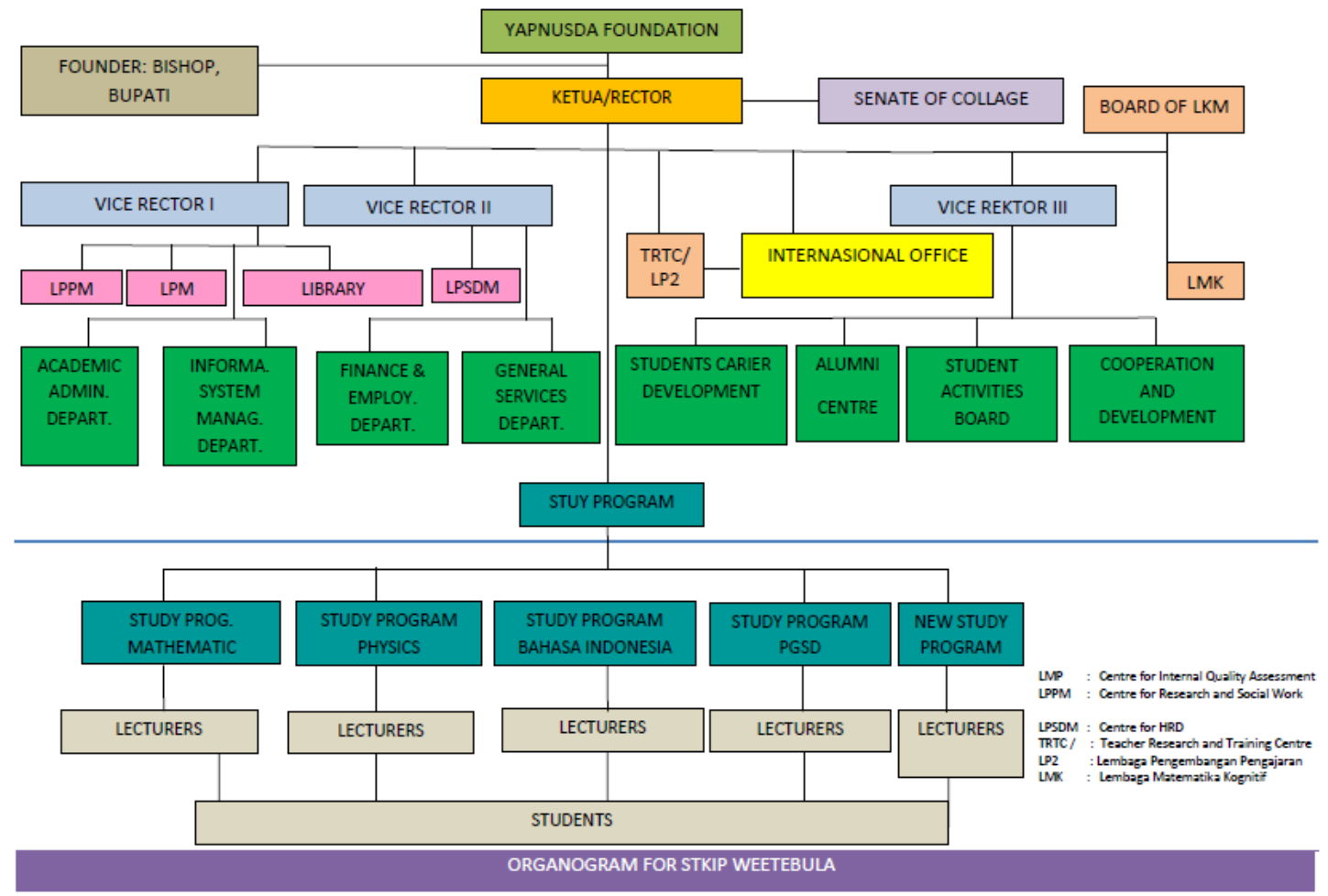

The figure 3. The organizational structure of STKIP Weetebula.

\section{Stakeholder Analysis}

It is important for STKIP Weetebula as an institution for higher educationto have a marketing plan to ensure that the current study programsand the new study programs that will be opened have sufficient numbers of students.Stakeholders are an important aspect that needs to be considered when creating a marketing plan. STKIP Weetebula needs to select the most influential stakeholders that will be involved in designing a marketing planning so that the goal of increasing the number of students as stated in the Long-term Development Planning (RIP) and Strategic Planning (Renstra) can be achieved.

The first step is to determine the key stakeholders that involve in marketing planning. A stakeholder analysis is used to determine the key stakeholders. The stakeholder analysis will help STKIP Weetebula to select and utilize one or more of its stakeholders to ensure the purpose of marketing planning can be achieved efficiently and effectively. Creating a marketing plan that involves all stakeholders would be better for achieving the goals of marketing, but STKIP Weetebula has limited resources. Therefore, it is necessary to choose only the main or key stakeholders who play an important role on reaching the objective of marketing planning.

This paper discusses up to the 3rd stage of stakeholder analysis to determine key stakeholders who are expected to have the most influence aspect in increasing the acceptance of new students of STKIP Weetebula. The three main stages of stakeholder analysis are as follows:

1. Identify all stakeholders owned by STKIP Weetebula including the internal or external stakeholders. STKIP Weetebula has the following stakeholders:

\begin{tabular}{|l|l|l|}
\hline No & $\begin{array}{l}\text { Stakeholder } \\
\mathrm{s}\end{array}$ & \\
\hline 1 & Students & $\begin{array}{l}\text { The studentsare one of the } \\
\text { main stakeholders and } \\
\text { beneficiary for STKIP } \\
\text { Weetebula. Students are the } \\
\text { main source of financing of } \\
\text { STKIP Weetebula }\end{array}$ \\
\hline 2 & Lecturers & $\begin{array}{l}\text { Lecturers and staff are the } \\
\text { main provider of education } \\
\text { services for STKIP } \\
\text { Weetebula students. There } \\
\text { are several lecturers who } \\
\text { also serve as leaders at } \\
\text { middle management such as } \\
\text { head of study programs, } \\
\text { head of departments, and } \\
\text { Head of work units. }\end{array}$ \\
\hline 3 & Yapnusda & $\begin{array}{l}\text { Yapnusda is the legal holder } \\
\text { of STKIP Weetebula. All } \\
\text { lecturers and staffs in } \\
\text { STKIP }\end{array}$ \\
\hline
\end{tabular}




\begin{tabular}{|c|c|c|}
\hline & & $\begin{array}{l}\text { areYapnusda employees'. } \\
\text { Regulations such as Statutes } \\
\text { and Employees Regulation } \\
\text { are determined by Yapnusda }\end{array}$ \\
\hline 4 & $\begin{array}{l}\text { Bishop } \\
\text { Weetebula }\end{array}$ & $\begin{array}{l}\text { The Bishop of Diocesan } \\
\text { Weeetebula is the head of } \\
\text { the local Catholic church on } \\
\text { Sumba Island and the } \\
\text { founder of STKIP } \\
\text { Weetebula }\end{array}$ \\
\hline 5 & The Bupati & $\begin{array}{l}\text { The Bupati is the head of } \\
\text { local government/district of } \\
\text { Southwest Sumba and the } \\
\text { founder of STKIP } \\
\text { Weetebula }\end{array}$ \\
\hline 6 & Donors & $\begin{array}{l}\text { Donors are organizations or } \\
\text { individuals who provide } \\
\text { financial, material, and } \\
\text { manpower support to } \\
\text { STKIP Weetebula. The } \\
\text { STKIP donors are Misereor } \\
\text { Germany, German KMW, } \\
\text { German AGEH, German } \\
\text { Ambassador, Donders } \\
\text { Foundation, Save the } \\
\text { Children, local NGO, } \\
\text { andprovincial government } \\
\text { of NTT }\end{array}$ \\
\hline 7 & Alumni & $\begin{array}{l}\text { Alumni is a graduate student } \\
\text { of STKIP Weetebula who } \\
\text { has graduated and worked } \\
\text { as a teacher in various } \\
\text { schools on Sumba Island or } \\
\text { outside Sumba }\end{array}$ \\
\hline 8 & $\begin{array}{l}\text { Parents of } \\
\text { Students }\end{array}$ & $\begin{array}{l}\text { Parentsof } \\
\text { Studentsareresponsible for } \\
\text { supporting fund(fee, } \\
\text { allowance, transport, meals) } \\
\text { for STKIP students }\end{array}$ \\
\hline 9 & $\begin{array}{l}\text { School } \\
\text { partner }\end{array}$ & $\begin{array}{l}\text { School partner is a partner } \\
\text { school where students of } \\
\text { STKIP conduct the teacher } \\
\text { practice program(PPL)anda } \\
\text { future alumni workplace. }\end{array}$ \\
\hline 10 & Kopertis & $\begin{array}{l}\text { Kopertis is a private } \\
\text { university coordinator for } 3 \\
\text { provinces i.e. Bali, NTB, } \\
\text { and NTT.Kopertis is } \\
\text { workingunder the ministry } \\
\text { of education.Alternative: } \\
\text { Kopertis is an institution } \\
\text { working under the ministry } \\
\text { of education to coordinate } \\
\text { private universities in } \\
\text { provinces Bali, NTB, and } \\
\text { NTT. }\end{array}$ \\
\hline
\end{tabular}

\begin{tabular}{|l|l|l|}
\hline 11 & DIKTI & $\begin{array}{l}\text { DIKTI is a department that } \\
\text { manages all higher } \\
\text { institutions in Indonesia }\end{array}$ \\
\hline 12 & $\begin{array}{l}\text { University/ } \\
\text { Higher } \\
\text { education }\end{array}$ & $\begin{array}{l}\text { A college or higher } \\
\text { education institution in } \\
\text { Sumba Island, a competitor } \\
\text { in seizing the potential } \\
\text { student candidates. }\end{array}$ \\
\hline 13 & $\begin{array}{l}\text { Local } \\
\text { Church }\end{array}$ & $\begin{array}{l}\text { a partner of STKIP } \\
\text { Weetebula as an } \\
\text { organization that delivers } \\
\text { announcements from STKIP } \\
\text { to society/church } \\
\text { community }\end{array}$ \\
\hline 14 & $\begin{array}{l}\text { Local } \\
\text { Community } \\
\text { the compunity living around } \\
\text { Weetebula.They provide } \\
\text { boarding houses andopen } \\
\text { small shopsfor students. }\end{array}$ \\
\hline
\end{tabular}

2. Identify the needs and interests of stakeholders (interest).

This stage identifies how stakeholders interest in STKIP Weetebula particularly associated with the marketing planning objectives, to increasethe number of studentsat STKIPWeetebula.This stage can determine whether the stakeholders have an interest in examplefrom a low to a high interest, and power owned for example from a lowtoa high power. In this stage (low or high) interest and power of stakeholders to increase the number of students of STKIP will be assessed. Based on the interest and power of stakeholders in marketing planning, the existing stakeholders can be classified as follows:

a. primary stakeholders are those who are mostly affected both positive and negative from the action of the marketing planning. These stakeholders are students, lecturers, staff, Yapnusda, alumni,

b. secondary stakeholders are those who are indirectly affected by the marketing planning activities.Stakeholder belong to this category are student parents, school partners, Yapnusda, Bishop, Bupati, donors, Kopertis, DIKTI, local churches, other universities, and local communities.

c. Key stake holders may include primary or secondary stakeholders including those who have significant influence on marketing planning to increase the number of STKIP Weetebula students ie. students, lecturers, staff, Yapnusda, alumni

3. Classify stakeholder interests using stakeholder mapping.

There are four areas related to the previous stages can be seen in Figure 4 below: Low Power-Low Interest (Monitor), Low Power-High Interest (Keep informed), 
High Power-Low Interest (Keep satisfied) and High Power-High Interest (Manage Closely).

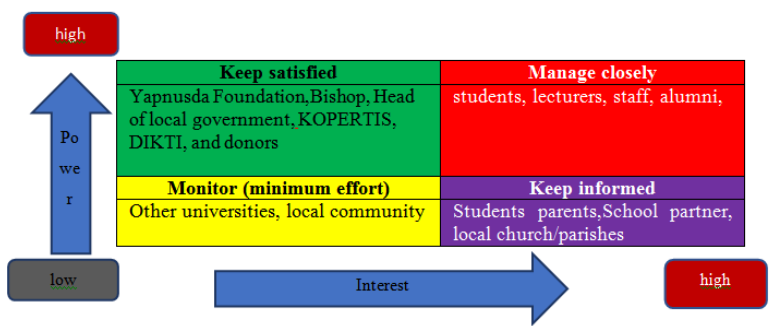

Figure 4. The Stakeholder Mapping (Mendelow, 1981)

The existing stakeholder mapping shows that lecturers, staffs, students, andalumni are key stakeholders who have a big impact on the increase in the number of prospective students who enroll in STKIP.

Alumni is one of the key stakeholder for STKIP Weetebula to increase the prospective student of STKIP Weetebula, it is necessary to create a marketing plan for prospective students of STKIP Weetebula. STKIP Weetebula is one of the producers of teachers in the island of Sumba, so to attract interest to prospective students alumni who are teachers in various (high) schools on the island of Sumba can be the spearhead that convey information or market STKIP to prospective students.

Having known the stakeholders who have influenced in the recruitment of prospective students then the next step is to make a marketing plan that involves alumni to achieve the objective of the marketing planning.

\section{The application of Model 7Ps Marketing Mix at for STKIP Weetebula}

Model 7Ps Marketing Mix(product, price, place, promotion, people, physical evidence, and process)is the tool used in applying marketing strategy. The main objective isto increase the number of students of STKIP Weetebula. This model is choosen to design marketing planning using alumni as a key stakeholder. It is selected from various marketing management models availabledue to the following reasons:

1. The 7Ps model will enable education institution to address the market situation and to follow the objective.

2. Most of the variables of this model can represent almost all the variables that exist in educational institutions compared to some other models such as Ansoff model, The McKinsey 7s. As an example, Ansof model focuses more on the four strategies, market penetration, market develoments, product development, and diversification. A higher institution such as STKIP has a wider service that focuses more on human development.

3. All the variables of the 7 Ps could affect each other to bring some impact in the marketing mix.

\section{Product}

Kotler (1999: 11) defines "the product as everything that can be offered to the market to meet the needs of its students, alumni, donors, and other market and consumer publics". The product is the whole object or process that gives some value to the consumer. In the context of educational services, products are services offered to customers in the form of reputation, prospects and variations of choice. For instance, higher-ranked educational programs (classes, library and information services, computer laboratory), recreational programs (sports facilities, art and dance clubs), personal-growth programs and services (counseling centers, religious organizations, advisors), curative services (health center), and future-planning programs and services (career counseling, placement service, and so on).STKIP Weetebula could compete among other higher institutions when "it offers satisfaction on courses, degree programs, career preparation, and other services and benefits on its markets. In return, it receives needed resources-tuition payments, donations, volunteers, money, time, and energy "(Kotler and Fox, 1995)

In addition, Kotler and Fox (1995) state that "these programs and services are experiences, not tangible products. Most services are intangible, inseparable, variable, and perishable, existing only in the presence of the recipient, the student or another person. Educational services usually combine both tangible and intangible cornponents, in that provided services may require classroom space, instructional media, books, desks, and other physical goods. Each service can be examined as the core offer the benefit that the customer is really seeking; the tangible offers the features, quality, packaging, and branding; and the augmented offerconvenience, guarantees, financing, and other advantages".

STKIP Weetebula needs to ensure that the products offered to customers are in line with the institution's development strategy that has been created in 2015 as well as with the needs of the people in this area. In institutional development strategies, STKIP Weetebula recognizes that programs and services will go through a life cycle of introduction, growth, maturity, and (often) decline. For that, it needsan adaptation and modernization process for programs and services to be offered. STKIP Weetebula realizes that from 4 courses currently owned, PGSD is the favorite study program over the last few years. It is due to the high demand of elementary school teachers in Sumba Island. It is predicted that the number of elementary school teachers will be saturated in the next 4 or 5 years. To that end, STKIP Weetebula needs to add new study programs that are needed by the community. Currently, STKIP is planning to open 3 new study programs, Catholic Religious Education Program, Science Education Study Program and Early Childhood Education Program (PAUD). 
To ensure that existing study programs and new courses are awarded to students, STKIP Weetebula seeks to graduate excellent prospective teachers in the field of intracurricular, and extracurricular teaching. The way that is done to equip students to excel in everything is as follows:

a. In the field of intracurricular teaching and learning that is by relying on professional lecturers in delivering their knowledge to learners, lecturers who teach should be in accordance with their respective fields so that students can receive knowledge and understand it.

b. In the extracurricular field STKIP Weetebula equips students with extracurricular competencies which can be chosen by students in accordance with their hobbies or talents that they are interested in through various student activities in sports, arts, technology, language, organizations such as scouts, and in providing IT, books, magazines, etc.

By providing quality services to students, they will be marketing for STKIP Weetebula while doing practical work such as SPS and PPL. After graduating from STKIP Weetebula and working as a teacher then they will be assessed by other costumers or prospective students. In addition, to strengthen the relationship with alumni, the institution has established the alumni network of STKIP Weetebula. Periodically, through alumni gatherings, the institution introduces new products or services that have been improved or added by STKIP.

\section{Price}

Price is the amount of money that consumers must pay to get a product or service. Price in the context of educational services is all expenses incurred to obtain the offered educational services. Elements of educational prices are considered regarding the pricing of tuition fees, building investment, laboratory, and others. "Pricing decisions are important to educational institutions because they depend on revenues to operate. Price is part of the marketing mix and should be considered as an element of strategic planning, including the role of price and fmancial aid in the institution's mission and goals "(Kotler and Fox, 1995: 326-327).

Therefore, setting prices for most educational programs should take into account the cost-oriented, customer demand oriented, and competitiveness factors. The institution must consider customer demand oriented, and competition-oriented factors when setting prices, "the institution should consider (1) the effects of a given pricing policy on enrollment, and (3) the degree to which a particular pricing policy may encourage acceleration. In addition, the institution must weigh (4) price charged by comparable competing institutions, and (5) the effects of its own price levels and price changes on the actions of such competitors. " (Kotler and Fox, 1995: 310)

STKIP Weetebula is a private institution that primarily depends on tuition fees to keep operating and, therefore, pricing issues are very important. Tuition covers most of the operating expenses of this institution ( 80 percent) and the rest comes from donors.

Costing in STKIP Weetebula is determined based on the meeting of STKIP with the legal holder Yapnusda and considering some suggestions from lecturers and staff, students, and alumni. STKIP Weetebula invites alumni representatives to provide input and consideration regarding the tuition fee. In addition, STKIP Weetebula develops a questionnaire for the alumni and students to find out their views on the amount of tuition fees set by the institution.

Payment of tuition fee at STKIP Weetebula is made to make it easier for students coming from low income family. Students are allowed to pay the tuition fee for 1 semester during the semester. Since its establishment in 2013, STKIP Weeetebula has raised fee by 5\% in 2016. Tuition fees at STKIP Weetebula are lower than at the two other universities in the region.

In addition, STKIP Weetebula set a different tuition fees among the 4 courses offered. Students in the Primary School Teacher Education Study Program pay a little more than three other study programs. The low and different prices strategy while trying to maintain the quality of service are expected to attract many prospective students toenrol at STKIP Weetebula.

\section{Place}

The institution's location can have four differentmeanings. It can refer to the absolute place in which the institution exists, it can refer tothe character of the area in which the institution is located, it can refer to a decision-making areafor an educational institution, and it can refertowhere its actual and prospective students live. (Kotler and Fox, 1995:333)

Location means where the service company is headquartered and conducts activities. In the context of higher education services place is where the college is located. The location of the school is more or less a preference to the prospect in determiningthe choice. Strategic location, convenient and easy to reach will be the main attraction. The place in the Education service is a combination of location and decision on the distribution channel. The location of STKIP Weetebula is somewhat unique because it is in the middle of the savana, about $8 \mathrm{~km}$ from downtown Weetebula and Tambolaka Airport. Location STKIP Weetebula is on its way to one of the Tourist Destinations on Sumba Island, Mananga Aba beach. Many lodgings are rented out around the campus so that students have no trouble finding a place to live. STKIP campus is located in the middle of cultivated fields and surrounded by trees make this place a fresh air location, away from pollution so as to support students feel comfortable participating in the 
process of teaching and learning.

The strategic location of STKIP, not far from the city center and on the way to one of the tourist destinations on the island of Sumba makes it easy for students and alumni to reach the campus location. One of the difficulties to look for is the lack of adequate public transportation from downtown to campus.

\section{Promotion}

Promotion is the activity of communicating the sale of products in the market that is directly related to the community. Promotion aims to provide information and convince consumers of the benefits of the resulting product. Promotional activities that can be done is by way of advertising through the media TV, radio, newspapers, bulletins, and others. Sales promotion can also be done through educational exhibitions, making direct contact with prospective students and conducting community relations activities.

The promotions used by STKIP Weetebula include:

a. Advertise STKIP Weetebula with it's various achievements and advantages into print media and electronic media (http: // www.stkipweetebula.co.id and social media like facebook ).

b. Fostering good communication to the surrounding community with the holding of research and services to the surrounding community, especially through the practice of teaching in schools and learning programs in the villages.

c. Holding regular meetings with alumni to help promote STKIP Weetebula

d. Inviting principals of high school and vocational schools to campus to listen to promotions.

e. Distribute flyers to secondary schools (SMA/SMK) in Sumba

f. Installing banners.

\section{People}

People in the educational context are those who are involved in the process of reconciling educational services such as lecturers and staff. These educators and educational resources are very important even spearheading the process of providing educational services to students. In relation to the marketing of services these people function as service providers. STKIP Weetebula who owns and provides educational services are lecturers and staff.Lecturers provide education services through good learning, according to their fields, staff help to smooth the teaching and learning process and other activities.

\section{Physical Evidence}

Physical evidence is the physical environment in which services are created and the providers directly interact with their customers. There are two kinds of physical evidence, firstly regarding the design and layout of the building for classrooms, offices, library, sports field and other supporting facilities.Secondly, supporting evidence such as the process of services to students and others. The services provided by STKIP Weetebula include the attitude of the lecturers and the staff who are polite and friendly to the costumers, respect to the students, listening to the suggestions from alumni and parents of students.

STKIP Weetebula has various facilities for educational activities such as buildings which include: class rooms (16 rooms), office ( 2 buildings), library (1 room) lecture room (1 Building), hall (1 building), laboratory (4 buildings). In addition, there are various other supporting facilities such as football field, volleyball, student dormitory, canteen, college bus, internet facilities.

\section{Process}

Process is a procedure or mechanism in a series of activities to deliver services from producer to consumer. In the context of process education services is the educational process that supports the implementation of the process of teaching and learning activities to form the desired product/graduate (Imam Machali, 2015: 408412).The success of a marketing can not be separated from the process. Initially, STKIP Weetebula's marketing strategy is only by distributing flyers and installing banners in schools, roads and public places, but because of the advancement of STKIP Weetebula technology has new innovations, such as using print media and technology to promote its services.

\section{References}

Gibbs, P and Knapp, M. 2002. Marketing Higher and Further Education. Kogan Page. London.

UK.

Lupiyoadi, Rambat and Hamdani, A. 2006. Manajemen Pemasaran Jasa, Jakarta. Salemba Empat.

Machali, Imam dan Ara Hidayat. 2015.. The Handbook of Education Management.Magister Pendidikan Islam Universitas Islam Negeri Sunan Kalijaga. Yogyakarta.

Kotler, Philip, and Fox, Karen F.A,. 1995. Strategic Marketing fo Educational Institutions. Prentice-Hall, Inc., Upper Saddle River, New Jersey. 
Kotler, Philip., Amstrong, G., Saunders, J., Wong, V. 1999. Principles of Marketing. PrenticeHall Europe.

Kotler, Philip. 2003. Marketing Management The Millenium Edition. Prentice-Hall International Inc.m Upper Saddle River, New Jersey.

Mendelow, A. L., 1981. Environmental Scanning-The Impact of the Stakeholder Concept. ICIS Proceedings. Paper 20. http://aisel.aisnet.org/icis1981/20.

STKIP Weetebula, 2015. Rencana Strategy Pengembangan STKIP Weetebula 20152020 (Strategic Planning of STKIP Weetebula 2015-2020).

STKIP Weetebula, 2015. Rencana Induk Pengembangan STKIP Weetebula 20152040 (Long-term Development Plan of STKIP Weetebula 2015-2040.

Thompson, R. 2018. Stakeholder Analysis Winning Support for Your Project. https://www.mindtools.com/pages/article/n ewPPM_07.htm. (Accesed 14 March 2018)

Tjiptono, Fandy. 2014. Pemasaran Jasa, Yogyakarta: Penerbit Andi

Weihrich, H., 1982. The TOWS matrix-A tool for situational analysishttps://www.sciencedirect.com/jour nal/long-rangeplanning/vol/15/issue/2(Accesed 14 March 2018) 